\title{
EXPERIMENTAL STUDY ON THE BEHAVIOUR OF RETEMPERED CONCRETE
}

\author{
K. Uma Shankar ${ }^{1}$, K. Arun Prakash², M. Harshavardana Balaji ${ }^{3}$, S. Pradep Kumar ${ }^{4}$ \\ ${ }^{I}$ Assistant Professor, Department of Civil Engineering, Knowledge Institute of Technology, Kakkapalayam, Salem- \\ 637 504, Tamil Nadu, India \\ ${ }^{2}$ Assistant Professor, Department of Civil Engineering, Knowledge Institute of Technology, Kakkapalayam, Salem - \\ 637 504, Tamil Nadu, India \\ ${ }^{3}$ Assistant Professor, Department of Civil Engineering, Knowledge Institute of Technology, Kakkapalayam, Salem- \\ 637 504, Tamil Nadu, India \\ ${ }^{4}$ Assistant Professor, Department of Civil Engineering, Knowledge Institute of Technology, Kakkapalayam, Salem- \\ 637 504, Tamil Nadu, India
}

\begin{abstract}
Ready-mixed concrete industries, are faced with a common problem known as casting delay, which usually results in a considerable loss of workability, so that concrete may be unworkable. On the other hand, improper methods of handling, lack of site organization, work scheduling and breakdown of equipment are some other causes of unexpected long delays. In such situations engineers at site, many a time reject the concrete partially set and unduly stiffened due to the time elapsed between mixing and placing. It is required to see whether such a stiffened concrete could be used on work without undue harm with use of admixtures. The process of remixing of concrete, if necessary, with addition of just the required quantity of water is known as "retempering" of concrete. The main objective of this research work is to study the behaviour and quality of retempered concrete and making it acceptable in concrete industry which would otherwise go as waste, thus saving the man hours, money and material. To achieve the above objective the workability, near surface characteristics and strength properties of retempered concrete at different time intervals such as, after $15 \mathrm{~min}, 30 \mathrm{~min}, 45 \mathrm{~min}, 60 \mathrm{~min}, 75 \mathrm{~min}, 90 \mathrm{~min}, 105 \mathrm{~min}$ and $120 \mathrm{~min}$ are found.
\end{abstract}

Keywords: Retempering, workability, near surface characteristics, strength, behaviour, slump. $* * *$

\section{INTRODUCTION}

Concrete industries and, especially, ready-mixed concrete industries, are faced with a common problem known as casting delay, which usually results in a considerable loss of workability, so that concrete may be unworkable. Delay in the production and delivery of ready-mixed concrete is inevitable, which is influenced by the location of construction sites in relation to the central batching plant and traffic conditions on the route. On the other hand, improper methods of handling, lack of site organization, work scheduling and breakdown of equipment are some other causes of unexpected long delays. The practice of retempering is frequently performed to restore the initial slump and keep concrete workable at construction sites in order to cope with the need for expediting casting operations and reducing consolidation efforts. Retempering of concrete with water, superplasticizers or a combination of both, are the most common variants for resolving slump loss of concrete. However it is well-known that retempering with water alone results in a substantial strength loss, since extra water increases the water to cement ratio of the concrete mixture. In the case of ready-mixed concrete, when concrete is observed at the delivery point to have a lower-thanspecified workability, there may be one or more of three possible reasons: (a) Insufficient water batched initially (b) a higher rate of evaporation (or)(absorption by aggregate) than anticipated and (c) a higher rate of hydration than expected. Based on established research, the retempering water added to offset reduction in workability, due to reasons (a) or (b), will not result in strength reduction, whereas extra water to combat (c) will result in a lower strength, due to some increase in the water to cement ratio. On the other hand, retempering with a superplasticizer would be beneficial in terms of the strength loss experienced [1].

One of the adverse effects of hot weather concreting is loss of slump. Delay in the delivery of ready mixed concrete has the same result and leads many people in the concrete industry to regain the original slump by adding water, a process known as 'retempering'. Ready-mixed (RMC) concrete, which is mixed at the plant, using a normal, welldesigned concrete mix, should arrive at its destination with sufficient workability to enable it to be properly placed and fully compacted. In such circumstances, where there is a significant period of time between mixing and placing the concrete, there will be a noticeable reduction in the workability of the fresh concrete. If for any reason, the placement of the concrete is unduly delayed, then it may stiffen to an unacceptable degree and site staff would normally insist on the rejection of a batch or otherwise good concrete on the grounds of insufficient workability. If not rejected, excessive vibration would be needed to attempt to fully compact the concrete, with the risk of incomplete 
compaction, expensive repair, or, at worst, removal of the hardened concrete. If abnormal slump loss in anticipated or if transport times are significant, then the intelligent use of admixtures can alleviate the potential workability difficulties, although at additional cost, and this practice is common place. However, in cases where unforeseen delay or some other cause has lead unexpectedly to poor workability, retempering of the concrete by water, while normally considered to be bad practice, may, in reality, be contemplated as a possible course of action. The increase in the water content of the concrete immediately prior to discharge will improve the consistency, but it is widely held that there must be a subsequent increase in the water / cement (w/c) ratio which will be detrimental to the hardened concrete. Adding water to a plastic mix to increase slump is an extremely common practice, even though it is not recommended because it increases the porosity of concrete. Concrete often arrives on site more than half an hour after initial mixing. Placement operations can take anywhere from 10 to 60 minutes, depending on the field conditions and the size of the load. When the slump decreases to an unacceptable level during the operations, water is added to the mix and, very often, experienced field inspectors will tolerate what can be termed 'reasonable' retempering, i.e., enough to increase slump by 50 or $60 \mathrm{~mm}$ [2].

\section{MATERIALS AND METHODOLOGY}

In this experimental work, ordinary Portland cement (OPC) 43 grade with cement content of $413.33 \mathrm{Kg} / \mathrm{m} 3$ conforming to IS: 8112 - 1989 [3] was used. Low calcium, class F dry fly ash from the silos of Raichur thermal power station conforming to IS: 3812 (Part 1) - 2003 [4] was used. Locally available river sand with specific gravity 2.58 belonging to zone II and locally available crushed angular aggregates of maximum nominal size $20 \mathrm{~mm}$ with specific gravity 2.61 were used confirming toIS: 383-1970 [5] and Water fit for drinking was used.

\subsection{Methodology}

In this experimentation, the mix design was done as per IS: 10262 - 2009 [6] and the obtained mix proportion is $1: 1.58: 2.71$ with W/C of 0.45 .

The quality of retempered concrete was checked w.r.t the following four different cases

- Retempered concrete without any addition

- Retempered concrete with extra 5\% cement + extra $5 \%$ water

- Retempered concrete with fly ash (20\% replacement by cement)

- Retempered concrete with fly ash (20\% replacement by cement) and extra $5 \%$ cement +extra $5 \%$ water

After thorough mixing of all the ingredients in dry state, the required quantity of water was added in the mix and thoroughly mixed. At this stage, the fresh concrete was kept for 15 minutes retempering time and thereafter workability tests were conducted, such as slump cone test, compaction factor test and Vee-Bee consistometer test. After conducting these tests the fresh concrete was poured into the moulds and the specimens were cast with sufficient compaction through tamping rod and vibrating table. This forms the retempered concrete for 15 minutes. Similarly the specimens were prepared with a retempering time of 30 minutes, 45 minutes, 60 minutes, 75 minutes, 90 minutes, 105 minutes and 120 minutes for all the above four combinations.

All the specimens were demoulded after 24 hours of their casting and were transferred to curing tank to cure them for 28 days. After 28 days of curing the specimens were tested for the compressive strength, tensile strength, flexural strength and shear strength as per IS specifications.

Near surface characteristic tests such as water absorption test and sorptivity tests were conducted to find percentage water absorption and sorptivity of retempered concrete. The sorptivity test determines the rate of capillary-rise absorption by a concrete cubes which rests on small supports in a manner such that only the lowest $30 \mathrm{~mm}$ of the cube is submerged. The increase in the water level of the prism with time is recorded.

It has been shown that there exists a relation of the form,

$$
S=t^{\frac{i}{0.5}}
$$

Where

$\mathrm{S}=$ sorptivity in $\mathrm{mm} / \mathrm{min} 0.5$.

$\mathrm{i}=$ depth of water level increased by capillary action, expressed in $\mathrm{mm}$.

$\mathrm{t}=$ time measured in minutes at which the depth determined [7].

For compressive strength test, the cubes of size $150 \mathrm{x} 150 \mathrm{x}$ $150 \mathrm{~mm}$ were cast and tested under compression testing machine of $2000 \mathrm{kN}$ capacity as per IS: 516-1959 [8]. For splitting tensile strength test, the cylinders of $150 \mathrm{~mm}$ diameter and length $300 \mathrm{~mm}$ were cast and were tested under compression testing machine as per IS: 5816-1999 [9]. For flexural strength test, beams of dimension $100 \times 100$ x $500 \mathrm{~mm}$ were cast and were tested on an effective span of $400 \mathrm{~mm}$ with two point loading as per IS: 516-1959 [8]. For shear strength test L shaped specimens as shown in fig. 1 were used. 


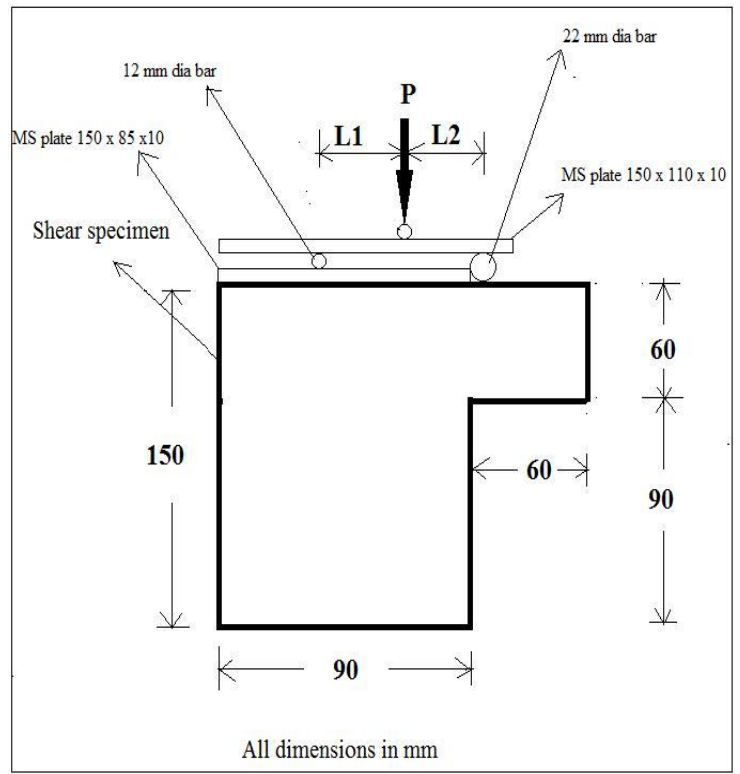

Fig.1 Shear test on L shaped specimen

The specimen was centrally placed on the compression testing machine and load is applied continuously and uniformly. The load is increased until the specimen fails and record the maximum load carried by each specimen during the test. Computation of the shear strength was done as follows.
Failure load $=\quad \frac{\text { PL1 }}{\mathrm{L} 1+\mathrm{L} 2}$

Shear strength $=$ Failure $\times 1000$

Where, $\mathrm{A}$

$\mathrm{P}=$ Load in $\mathrm{kN}$

$\mathrm{A}=$ Area of shear surface $=60 \times 150 \mathrm{~mm} 2 \mathrm{~L} 1=25 \mathrm{~mm}$ $\mathrm{L} 2=25 \mathrm{~mm}$.

\subsection{RESULTS AND DISCUSSIONS}

Table 1 gives the slump test results of different retempered concrete combinations for different retempering times, and fig. 2 shows the variation of slump. Table 2 gives the compaction factor test results of different retempered concrete combinations for different retempering times, and fig. 3 shows the variation of compaction factor. Table 3 gives the Vee-Bee test results of different retempered concrete combinations for different retempering times, and fig. 4 shows the variation of Vee-Bee time.

Table 1: Slump test results

\begin{tabular}{|c|c|c|c|c|}
\hline & & \multicolumn{3}{|c|}{ Slump $(\mathrm{mm})$ of retempered concrete } \\
\hline Retempering time & \multirow[t]{2}{*}{ without any } & with extra $5 \%$ & with fly ash $(20 \%$ & with fly ash (20\% replacement \\
\hline \multirow[t]{3}{*}{ (minutes) } & & cement + extra $5 \%$ & replacement by & by cement) and extra $5 \%$ \\
\hline & \multirow[t]{2}{*}{ additions } & & & \\
\hline & & water & cement) & cement + extra $5 \%$ water \\
\hline & & & & \\
\hline 0 & 10 & 15 & 20 & 25 \\
\hline 15 & 10 & 15 & 20 & 25 \\
\hline 30 & 10 & 15 & 20 & 25 \\
\hline 45 & 8 & 12 & 15 & 25 \\
\hline 60 & 8 & 12 & 15 & 20 \\
\hline 75 & 5 & 10 & 12 & 20 \\
\hline 90 & 5 & 8 & 10 & 15 \\
\hline 105 & 4 & 5 & 8 & 10 \\
\hline 120 & 0 & 3 & 4 & 5 \\
\hline
\end{tabular}

Table 2: Compaction factor test results

\begin{tabular}{|l|l|l|l|l|}
\hline \multirow{2}{*}{ Retempering time } & \multicolumn{3}{|l|}{ Compaction factor of retempered concrete } \\
\cline { 2 - 5 } & \multirow{2}{*}{ without any } & with extra 5\% & with fly ash $(20 \%$ & with fly ash (20\% replacement \\
\cline { 4 - 5 } & & cement + extra 5\% & replacement by & by cement) and extra 5\% \\
\cline { 5 - 6 } & additions & & cement) & cement + extra 5\% water \\
\cline { 5 - 5 } & & & & \\
\hline
\end{tabular}




\begin{tabular}{|l|l|l|l|l|}
\hline 0 & 0.865 & 0.869 & 0.882 & 0.896 \\
\hline 15 & 0.862 & 0.868 & 0.876 & 0.893 \\
\hline 30 & 0.860 & 0.868 & 0.875 & 0.885 \\
\hline 45 & 0.858 & 0.866 & 0.873 & 0.880 \\
\hline 60 & 0.857 & 0.861 & 0.865 & 0.871 \\
\hline 75 & 0.851 & 0.859 & 0.861 & 0.865 \\
\hline 90 & 0.847 & 0.854 & 0.858 & 0.863 \\
\hline 105 & 0.845 & 0.851 & 0.855 & 0.858 \\
\hline 120 & 0.844 & 0.848 & 0.852 & 0.853 \\
\hline & & & & \\
\hline
\end{tabular}

Table 3: Vee-Bee test results

\begin{tabular}{|c|c|c|c|c|}
\hline \multirow{4}{*}{$\begin{array}{l}\text { Retempering time } \\
\text { (minutes) }\end{array}$} & & \multicolumn{3}{|c|}{ Vee Bee time (sec) of retempered concrete } \\
\hline & \multirow{3}{*}{$\begin{array}{l}\text { without } \\
\text { any } \\
\text { additions }\end{array}$} & with extra 5\% & with fly ash $(20 \%$ & $\begin{array}{l}\text { with fly ash }(20 \% \\
\text { replacement }\end{array}$ \\
\hline & & cement + extra $5 \%$ & replacement by & $\begin{array}{l}\text { by cement) and extra } \\
5 \%\end{array}$ \\
\hline & & water & cement) & $\begin{array}{l}\text { cement }+ \text { extra 5\% } \\
\text { water }\end{array}$ \\
\hline 0 & 5 & 4 & 3 & 2 \\
\hline 15 & 5 & 4 & 3 & 2 \\
\hline 30 & 6 & 5 & 3 & 2 \\
\hline 45 & 6 & 5 & 4 & 2 \\
\hline 60 & 6 & 5 & 4 & 3 \\
\hline 75 & 7 & 6 & 4 & 3 \\
\hline 90 & 8 & 6 & 5 & 3 \\
\hline 105 & 8 & 7 & 5 & 4 \\
\hline 120 & 8 & 7 & 5 & 4 \\
\hline
\end{tabular}

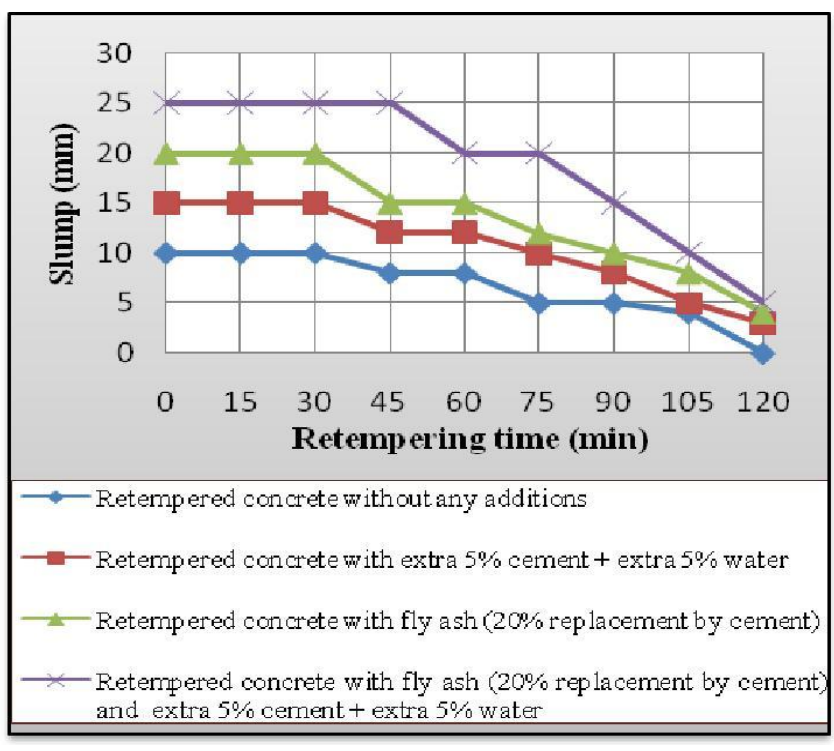

Fig. 2 Variation of slump

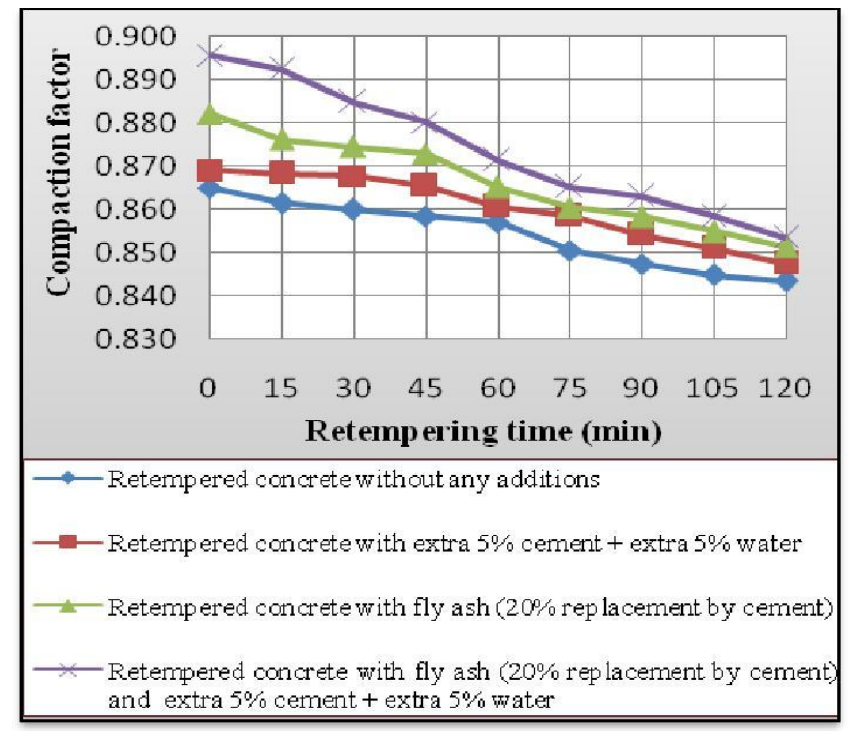

Fig. 3 Variation of compaction factor 


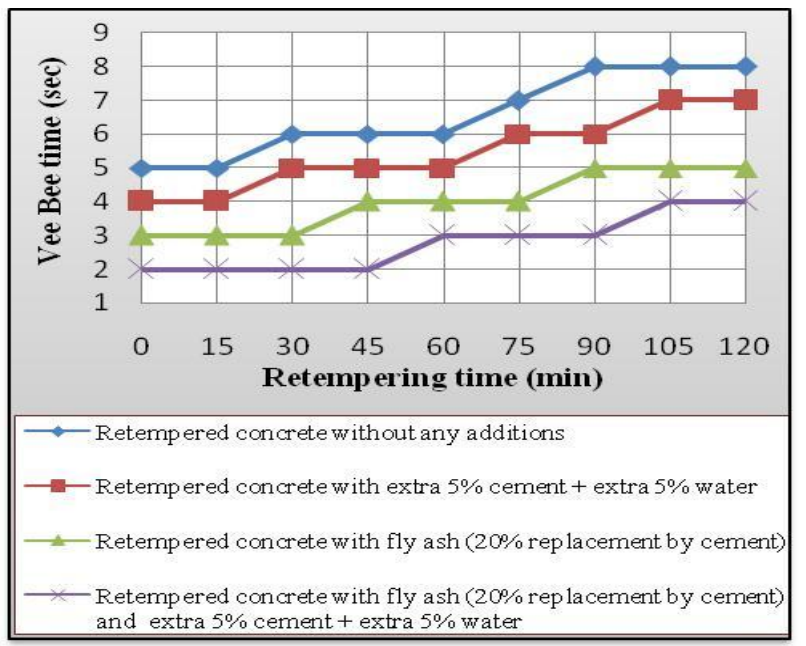

Fig. 4 Variation of Vee-Bee time

It is observed that workability as measured from slump, compaction factor and Vee-Bee degree go on decreasing as the retempering time increase. This is true for retempered concrete produced without any additions, produced with extra $5 \%$ cement and water, produced with $20 \%$ replacement of cement by fly ash, and produced with $20 \%$ replacement of cement by fly ash with extra $5 \%$ cement and water. This is due to the fact that as the retempering time increases the evaporation of water takes place from the concrete mass and also concrete starts losing its plasticity, thereby reducing workability. Thus it can be concluded that the workability goes on decreasing as the retempering time increase.

Also it is observed that workability as measured from slump, compaction factor and Vee-Bee degree is more for the retempered concrete produced with $20 \%$ replacement of cement by fly ash and with extra $5 \%$ cement and water as compared to other categories. Thisis true for all the retempering times. This is due to the fact that addition of fly ash and extra 5\% cement and water will help in keeping the concrete in plastic state for more time thus inducing the flow characteristics. Thus it can be concluded that the workability of retempered concrete produced with $20 \%$ replacement of cement by fly ash with extra $5 \%$ cement and water is high as compared to other categories of retempered concrete.

Table 4 gives the water absorption test results of different retempered concrete combinations for different retempering times, and fig. 5 shows the variation of water absorption. Table 5 gives the sorptivity test results of different retempered concrete combinations for different retempering times, and fig. 6 shows the variation of sorptivity.

Table 4: Water absorption test results

\begin{tabular}{|l|l|l|l|l|}
\hline \multirow{4}{*}{$\begin{array}{c}\text { Retempering time } \\
\text { (minutes) }\end{array}$} & & \multicolumn{3}{|l|}{ Water absorption (\%) of retempered concrete } \\
\cline { 2 - 5 } & without any & with extra 5\% & $\begin{array}{l}\text { with fly ash } \\
(20 \%\end{array}$ & with fly ash (20\% replacement \\
\cline { 2 - 5 } & additions & cement + extra 5\% & replacement by & by cement) and extra 5\% \\
\cline { 2 - 5 } & & water & cement) & cement + extra 5\% water \\
\cline { 2 - 5 } & & 0.776 & 0.742 & 0.735 \\
\hline 0 & 0.800 & 0.805 & 0.793 & 0.746 \\
\hline 15 & 0.853 & 0.835 & 0.821 & 0.770 \\
\hline 30 & 0.860 & 0.875 & 0.843 & 0.790 \\
\hline 45 & 0.928 & 0.899 & 0.851 & 0.849 \\
\hline 60 & 0.937 & 0.939 & 0.867 & 0.864 \\
\hline 75 & 0.955 & 0.953 & 0.921 & 0.901 \\
\hline 90 & 0.985 & 0.968 & 0.928 & 0.923 \\
\hline 105 & 1.002 & 0.991 & 0.944 & 0.942 \\
\hline 120 & 1.058 & & & \\
\hline
\end{tabular}

Table 5: Sorptivity test results

\begin{tabular}{|c|c|c|c|c|}
\hline & & \multicolumn{3}{|c|}{ Sorptivity $(\mathrm{mm} / \mathrm{min} 0.5)$ of retempered concrete } \\
\hline & \multirow[t]{2}{*}{ without any } & with extra $5 \%$ & $\begin{array}{l}\text { with fly ash } \\
(20 \%\end{array}$ & with fly ash (20\% replacement \\
\hline \multirow[t]{3}{*}{ (minutes) } & & cement + extra $5 \%$ & replacement by & by cement) and extra $5 \%$ \\
\hline & \multirow[t]{2}{*}{ additions } & & & \\
\hline & & water & cement) & cement + extra $5 \%$ water \\
\hline 0 & 4.52 & 4.39 & 4.00 & 3.87 \\
\hline 15 & 4.65 & 4.52 & 4.13 & 4.00 \\
\hline
\end{tabular}




\begin{tabular}{|l|l|l|l|l|}
\hline 30 & 4.78 & 4.65 & 4.26 & 4.13 \\
\hline 45 & 4.78 & 4.65 & 4.26 & 4.13 \\
\hline 60 & 4.91 & 4.65 & 4.26 & 4.13 \\
\hline 75 & 4.91 & 4.78 & 4.39 & 4.26 \\
\hline 90 & 5.03 & 4.91 & 4.52 & 4.39 \\
\hline 105 & 5.29 & 5.03 & 4.78 & 4.52 \\
\hline 120 & 5.42 & 5.16 & 4.91 & 4.65 \\
\hline
\end{tabular}

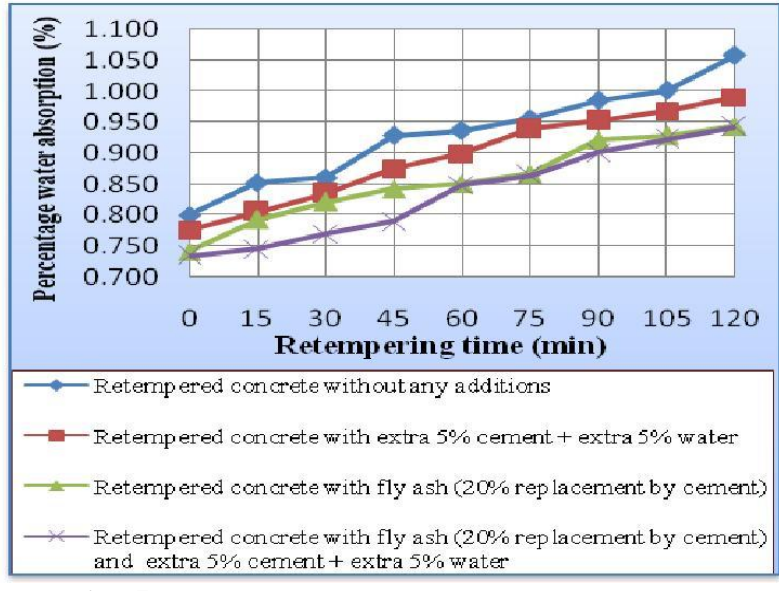

Fig. 5 Variation of water absorption

It is observed that near surface characteristics as measured from water absorption and sorptivity go on increasing as the retempering time increase. This is true for retempered concrete produced without any additions, produced with extra 5\% cement and water, produced with $20 \%$ replacement of cement by fly ash, and produced with $20 \%$ replacement of cement by fly ash with extra 5\% cement and water. This is due to the fact that as the retempering time increases the workability decreases. This results in improper compaction of concrete which may lead to many air- voids in the concrete mass, thereby increasing water absorption and sorptivity.Thus it can be concluded that the near surface characteristics such as water absorption and sorptivity goes on increasing as the retempering time increase.

Also it is observed that near surface characteristics as measured from water absorption and sorptivity is least for retempered concrete produced with $20 \%$ replacement of cement by fly ash with extra 5\% cement and water as compared to other categories. This is true for all the retempering times. This is due to the fact that addition of fly ash with extra 5\% cement and water induce plasticity to

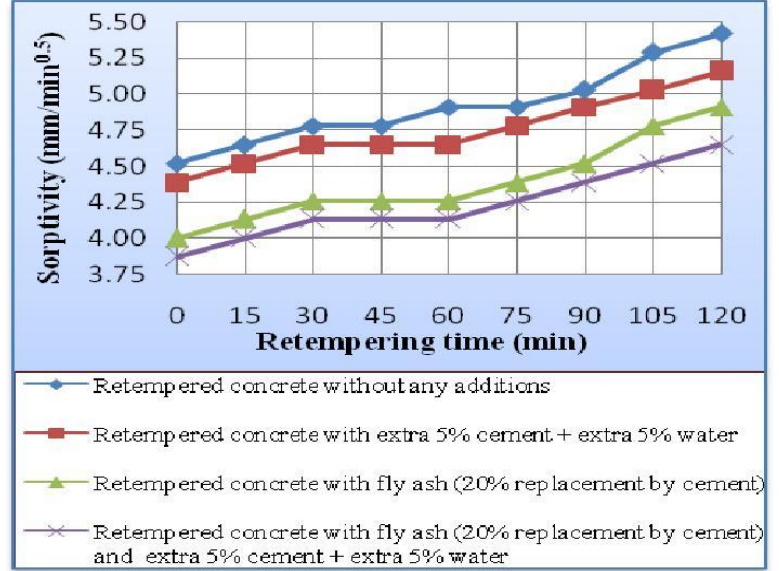

Fig. 6 Variation of sorptivity

concrete resulting in more workability. This concrete can be easily compacted thereby reducing the air voids. Thus it can be concluded that the near surface characteristics such as water absorption and sorptivity is least for retempered concrete produced with $20 \%$ replacement of cement by fly ash with extra 5\% cement and water as compared to other categories of retempered concrete.

Table 6 gives the results of compressive strength of retempered concrete for different combinations with different retempering times, and fig. 7 shows the variation of compressive strength. Table 7 gives the results of tensile strength of retempered concrete for different combinations with different retempering times, and fig. 8 shows the variation of tensile strength. Table 8 gives the results of flexural strength of retempered concrete for different combinations with different retempering times, and fig. 9 shows the variation of flexural strength. Table 9 gives the results of shear strength of retempered concrete for different combinations with different retempering times, and fig. 10 shows the variation of shear strength.

Table 6: Results of compressive strength

\begin{tabular}{|c|c|c|c|c|}
\hline & & \multicolumn{3}{|c|}{ Compressive strength (MPa) of retempered concrete } \\
\hline \multirow[t]{2}{*}{ Retempering time } & \multirow{3}{*}{ without any } & \multirow{2}{*}{ with extra 5\% } & \multirow{2}{*}{ with fly ash } & with fly ash $(20 \%$ \\
\hline & & & & \multirow{2}{*}{$\begin{array}{l}\text { replacement by cement) } \\
\text { and }\end{array}$} \\
\hline \multirow[t]{2}{*}{ (minutes) } & & \multirow[t]{2}{*}{ cement + extra 5\% } & \multirow{2}{*}{$\begin{array}{l}(20 \% \\
\text { replacement }\end{array}$} & \\
\hline & additions & & & $\begin{array}{l}\text { extra 5\% cement + extra } \\
5 \%\end{array}$ \\
\hline
\end{tabular}




\begin{tabular}{|c|c|c|c|c|}
\hline & & & & water \\
\hline 0 & 42.22 & 42.37 & 42.67 & 43.11 \\
\hline 15 & 42.81 & 43.26 & 43.41 & 43.56 \\
\hline 30 & 43.11 & 43.70 & 43.85 & 44.15 \\
\hline 45 & 43.41 & 44.15 & 44.44 & 44.89 \\
\hline 60 & 42.37 & 42.96 & 43.11 & 43.41 \\
\hline 75 & 41.48 & 42.07 & 42.37 & 42.67 \\
\hline 90 & 40.74 & 41.33 & 41.63 & 41.78 \\
\hline 105 & 40.00 & 40.15 & 40.44 & 40.74 \\
\hline 120 & 39.11 & 39.26 & 39.56 & 40.30 \\
\hline
\end{tabular}

Table 7: Results of tensile strength

\begin{tabular}{|c|c|c|c|c|}
\hline \multirow{3}{*}{ Retempering time } & & \multicolumn{3}{|c|}{ Tensile strength (MPa) of retempered concrete } \\
\hline & \multirow{5}{*}{$\begin{array}{l}\text { without } \\
\text { any } \\
\text { additions }\end{array}$} & \multirow{2}{*}{ with extra 5\% } & \multirow[t]{2}{*}{ with fly ash } & with fly ash $(20 \%$ \\
\hline & & & & \multirow{2}{*}{ replacement by cement) } \\
\hline \multirow[t]{4}{*}{ (minutes) } & & \multirow[t]{2}{*}{ cement + extra } & \multirow[t]{2}{*}{ (20\% replacement } & \\
\hline & & & & \multirow[t]{2}{*}{ and extra $5 \%$ cement +} \\
\hline & & \multirow[t]{2}{*}{$5 \%$ water } & \multirow[t]{2}{*}{ by cement) } & \\
\hline & & & & extra $5 \%$ water \\
\hline 0 & 3.68 & 3.77 & 3.82 & 3.91 \\
\hline 15 & 3.77 & 3.87 & 3.96 & 4.10 \\
\hline 30 & 3.87 & 3.96 & 4.10 & 4.20 \\
\hline$\overline{45}$ & 3.96 & 4.15 & 4.29 & 4.39 \\
\hline 60 & 3.87 & 4.01 & 4.10 & 4.20 \\
\hline 75 & 3.68 & 3.87 & 3.91 & 3.96 \\
\hline 90 & 3.58 & 3.68 & 3.72 & 3.82 \\
\hline 105 & 3.44 & 3.49 & 3.54 & 3.63 \\
\hline 120 & 3.30 & 3.39 & 3.44 & 3.54 \\
\hline
\end{tabular}

Table 8: Results of flexural strength

\begin{tabular}{|c|c|c|c|c|}
\hline & & \multicolumn{3}{|c|}{ Flexural strength (MPa) of retempered concrete } \\
\hline \multirow[t]{2}{*}{ Retempering time } & & \multirow[t]{2}{*}{ with extra 5\% } & \multirow{2}{*}{ with fly ash } & \multirow{3}{*}{$\begin{array}{l}\text { with fly ash }(20 \% \\
\text { replacement by cement) }\end{array}$} \\
\hline & \multirow{2}{*}{ without any } & & & \\
\hline \multirow[t]{4}{*}{ (minutes) } & & \multirow[t]{2}{*}{ cement + extra } & \multirow[t]{2}{*}{ (20\% replacement } & \\
\hline & \multirow[t]{3}{*}{ additions } & & & \multirow[t]{2}{*}{ and extra 5\% cement + } \\
\hline & & \multirow[t]{2}{*}{$5 \%$ water } & \multirow[t]{2}{*}{ by cement) } & \\
\hline & & & & extra $5 \%$ water \\
\hline 0 & 6.47 & 6.80 & 7.13 & 7.40 \\
\hline 15 & 6.93 & 7.20 & 7.40 & 7.67 \\
\hline 30 & 7.20 & 7.47 & 7.93 & 8.07 \\
\hline 45 & 7.73 & 7.87 & 8.27 & 8.73 \\
\hline 60 & 6.80 & 7.20 & 7.47 & 7.87 \\
\hline 75 & 6.47 & 6.80 & 7.20 & 7.60 \\
\hline 90 & 6.07 & 6.47 & 6.80 & 7.33 \\
\hline 105 & 5.67 & 6.13 & 6.53 & 6.80 \\
\hline 120 & 5.47 & 5.80 & 6.33 & 6.60 \\
\hline
\end{tabular}


Table 9: Results of shear strength

\begin{tabular}{|c|c|c|c|c|}
\hline & & Shear strength & f retempered concre & \\
\hline \multirow[t]{2}{*}{ Retempering time } & & with extra $5 \%$ & with fly ash & with fly ash $(20 \%$ \\
\hline & \multirow{2}{*}{$\begin{array}{l}\text { without } \\
\text { any }\end{array}$} & & & \multirow[t]{2}{*}{ replacement by cement) } \\
\hline \multirow[t]{4}{*}{ (minutes) } & & \multirow[t]{2}{*}{ cement + extra } & \multirow[t]{2}{*}{ (20\% replacement } & \\
\hline & \multirow[t]{2}{*}{ additions } & & & \multirow[t]{2}{*}{ and extra $5 \%$ cement +} \\
\hline & & \multirow[t]{2}{*}{$5 \%$ water } & \multirow[t]{2}{*}{ by cement) } & \\
\hline & & & & extra 5\% water \\
\hline 0 & 3.70 & 4.07 & 4.26 & 4.44 \\
\hline 15 & 4.07 & 4.26 & 4.44 & 4.63 \\
\hline 30 & 4.26 & 4.63 & 4.81 & 5.00 \\
\hline 45 & 4.63 & 4.81 & 5.19 & 5.37 \\
\hline 60 & 4.44 & 4.63 & 4.81 & 5.00 \\
\hline 75 & 3.89 & 4.07 & 4.44 & 4.81 \\
\hline 90 & 3.52 & 3.70 & 4.07 & 4.44 \\
\hline 105 & 3.15 & 3.33 & 3.70 & 4.07 \\
\hline 120 & 2.96 & 3.15 & 3.33 & 3.70 \\
\hline
\end{tabular}

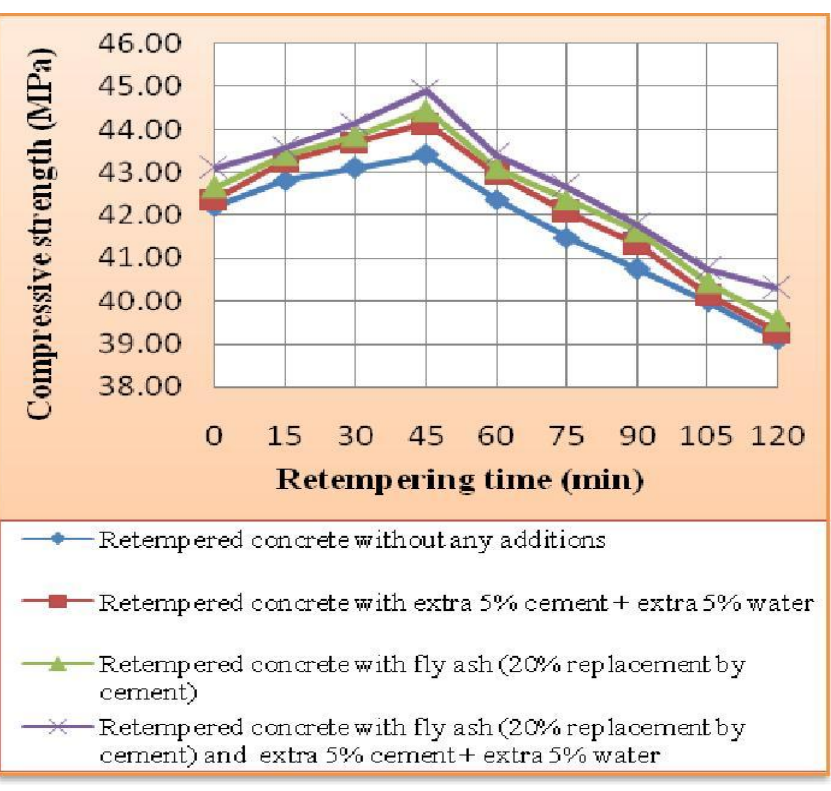

Fig. 7 Variation of compressive strength

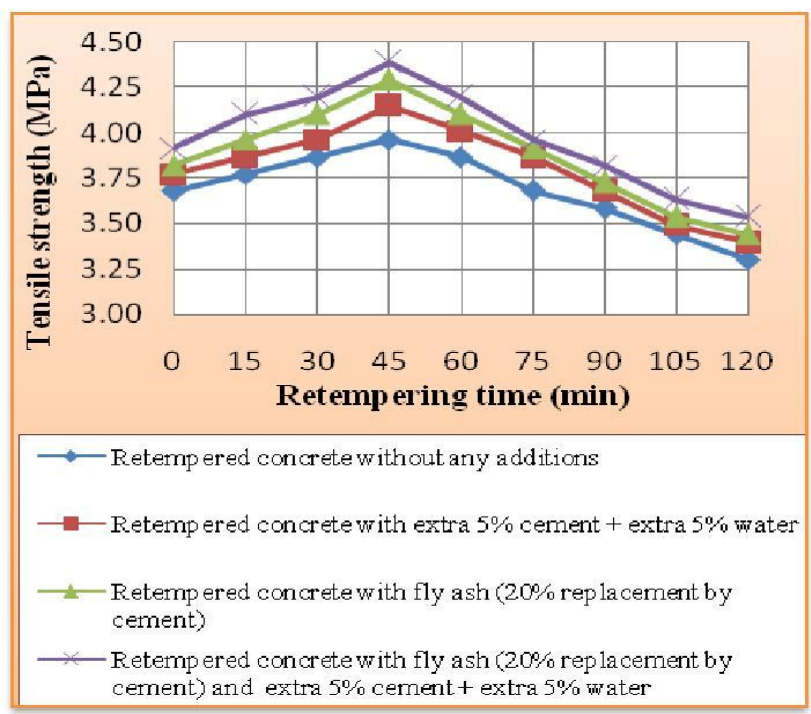

Fig. 8 Variation of tensile strength

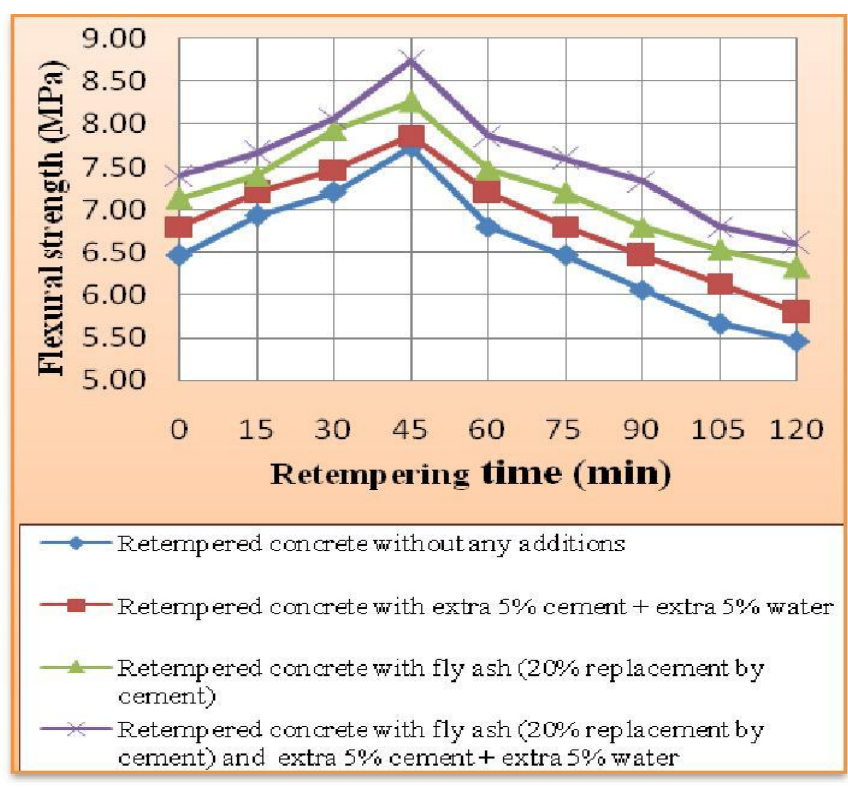

Fig. 9 Variation of flexural strength

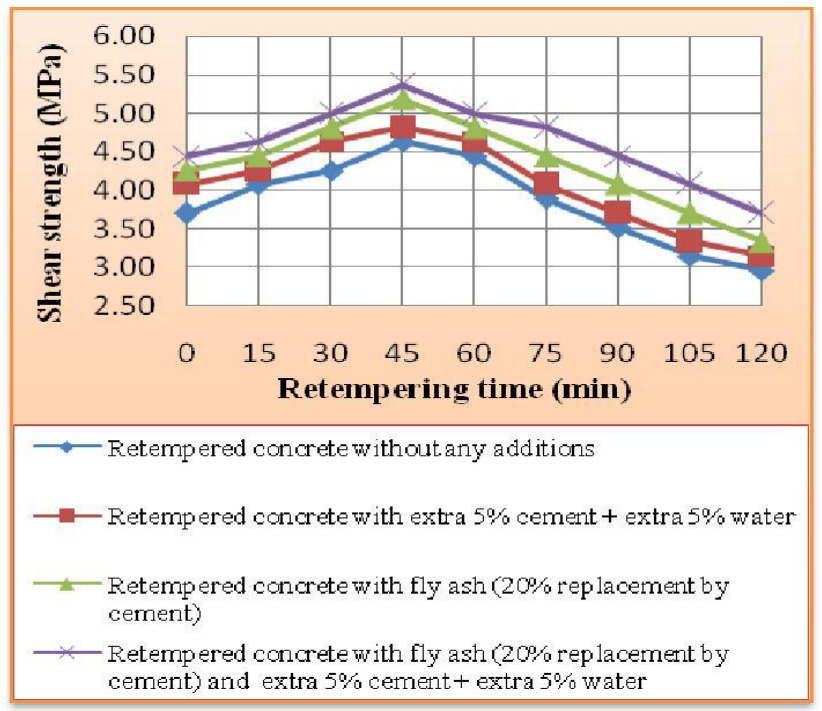

Fig. 10 Variation of shear strength 
It is observed that compressive strength, tensile strength, flexural strength and shear strength of retempered concrete goes on increasing up to 45 minutes of retempering time. Thereafter all the strengths start decreasing. This is true for retempered concrete produced without any additions, produced with extra 5\% cement and water, produced with $20 \%$ replacement of cement by fly ash, and produced with $20 \%$ replacement of cement by fly ash with extra $5 \%$ cement and water. This is due to the fact that above 45 minutes of retempering time the concrete looses the plasticity seriously and remixing the concrete beyond 45 minutes will not reunite the concrete particles to adhere together. Thus it can be concluded that compressive strength, tensile strength, flexural strength and shear strength of retempered concrete goes on increasing up to 45 minutes of retempering time. Therefore retempering can be allowed up to 45 minutes.

Also it is observed that compressive strength, tensile strength, flexural strength and shear strength of concrete is more for retempered concrete produced with $20 \%$ replacement of cement by fly ash with extra $5 \%$ cement and water as compared to other categories. This is true for all the retempering times. This is due to the fact that addition of fly ash and extra 5\% cement and water will help in keeping the concrete in plastic state which helps in thorough compaction of concrete resulting in higher strength.Thus it can be concluded that compressive strength, tensile strength, flexural strength and shear strength of concrete is more for retempered concrete produced with $20 \%$ replacement of cement by fly ash with extra $5 \%$ cement and water as compared to other categories.

\section{CONCLUSIONS}

Following conclusions can be drawn based on the experimentations conducted on the retempered concrete.

- Workability goes on decreasing as the retempering time increase.

- Workability of retempered concrete produced with $20 \%$ replacement of cement by fly ash with extra $5 \%$ cement and water is high as compared to other categories of retempered concrete.

- Near surface characteristics such as water absorption and sorptivity goes on increasing as the retempering time increase.

- Near surface characteristics such as water absorption and sorptivity is least for retemperedconcrete produced with $20 \%$ replacement of cement by fly ash with extra $5 \%$ cement and water as compared to other categories of retempered concrete.

- Compressive strength, tensile strength, flexural strength and shear strength of retemperedconcrete goes on increasing up to 45 minutes of retempering time. Therefore retempering can be allowed up to the time of 45 minutes.

- Compressive strength, tensile strength, flexural strength and shear strength of concrete is more for retempered concrete produced with $20 \%$ replacement of cement by fly ash with extra $5 \%$ cement and water as compared to other categories.

\section{REFERENCES}

[1]. IS: 8112 - 1989, "43 Grade ordinary Portland cement-Specifications" (First revision),BIS, New Delhi, May 1990.

[2]. IS: 3812 (Part 1) - 2003, "Pulverized fuel ash Specification" (Second revision),BIS, New Delhi, October 2003.

[3]. IS: 383 - 1970, "Specifications for coarse and fine aggregate from natural sources for concrete" (Second revision), BIS, New Delhi, April 1971.

[4]. IS: 10262 - 2009, "Concrete mix proportioning Guidelines" (First revision), BIS, New Delhi, July 2009.

[5]. IS: 10262-1982 Recommended Guidelines for Concrete Mix Design.

[6]. SANTHAKUMAR.A.R, "Concrete Technology”, Oxford Publishing \& Co., New Delhi, 2007, First Edition.

\section{BIOGRAPHIES}

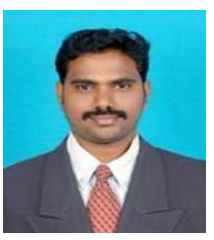

Prof.K.UmaShankar presently working as Assistant Professor in the department of Civil Engineering at Knowledge Institute of Technology. He has more than 4 years of teaching experience. He has published 5 papers in the reputed International and National journals \& Conferences.

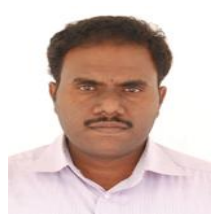

Mr.K.ArunPrakash is presently working as Assistant Professor in the Department of Civil Engineering at Knowledge Institute of Technology. He has more than 3 years of teaching experience. He has published 1 paper in the International Conference and 2 papers in the National Conferences.

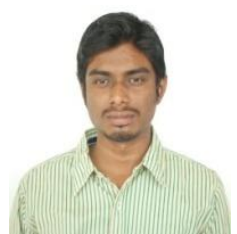

Mr.M.Harshavardana Balaji is presently working as Assistant Professor in the Department of Civil Engineering at Knowledge Institute of Technology. He has more than 2 years of teaching experience. He has published 1 paper in the International Conference and 2 papers in the National Conferences.

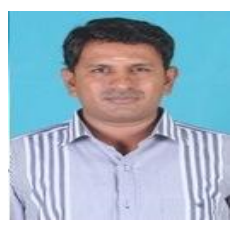

S.PradeepKumar is presently working as Assistant Professor in the Department of Civil Engineering at Knowledge Institute of Technology. He has more than 2 years of teaching experience. He has published 1 paper in the International Conference and 2 papers in the National Conferences. 